\title{
Antecedents of Turnover Intention Behavior among Nurses: A Theoretical Review
}

\author{
Mohammad Alhamwan ${ }^{1} \&$ NorazuwaBt Mat. ${ }^{1}$ \\ ${ }^{1}$ School of Business, University Utara Malaysia, Kedah, Malaysia \\ Correspondence: Mohammad Alhamwan, School of Business, University Utara Malaysia, Kedah, Malaysia. \\ E-mail: malhamwan@yahoo.com
}

Received: November 28, 2014

Accepted: January 19, 2015 Online Published: February 20, 2015

doi:10.5539/jms.v5n1p84

URL: http://dx.doi.org/10.5539/jms.v5n1p84

\begin{abstract}
The employees' turnover intention is one of the most popular subjects in the field of Human Resource Management. Moreover, the turnover problematic phenomenon is also still one of the most costly issues for HR managers in their efforts on human capital. Although turnover intention has been one of the most researched phenomenon in Human Resource Management (HRM), researchers still return to restudying this phenomenon because of its impact on service quality in any organization, moreover turnover intention has direct and indirect costs, both costs are critical, complicated, and serious. While the phenomenon of turnover intention in the nursing sector has a more serious impact than on any other sector, it has been recognized in both developing and developed countries. Organizational factors (Leadership, Pay Level, and Advancement Opportunities) have excessive impact on turnover intention among employees. Thus, this conceptual paper focuses on the organizational factors as the determinant of turnover intention among registered nurses. Approach: The literature was explored to acknowledge the accessible relationships among cross organizational factors (Leadership, Pay Level, and Advancement Opportunities) and turnover intention among registered nurses public hospitals. Conclusions: This conceptual paper provides an updated review of the literature on organizational factors and turnover intention. The practical implications as well as academic contributions were also presented.
\end{abstract}

Keywords: turnover intention, leadership, pays level, advancement opportunities

\section{Introduction}

Turnover intention behavior of employees is a major issue nowadays all over the world organizations, and almost among all industries. Turnover intention is one of top issues that has been researched and studied more than any other Human Resource Management (HRM) phenomenon, which is mean that this issue has not been solved yet. However, from time to time scholars and researchers return to restudying and digging deeper into this issue; the reason for that being the importance, influence, and cost of turnover intention on any organization. In addition to that, service quality which mainly provided by employees is another issue that could cost any management a large amount of cost and time, and could have several negative influences on any outcome (Morrell et al., 2004; Frank et al., 2004).

While the phenomenon of turnover intention in the nursing sector has a more serious impact than on any other sector, it has been recognized in both developing and developed countries. However, the increasing of elderly people in the developed countries with the shortage of nursing staff, combined with the shortage of nursing education institutions, and the age level of the nursing workforce in many countries (one out of four nurses in some developed countries is over 50 years old). In that the nursing sector has the highest turnover intention percentage, $41 \%$ of the nurses in USA, and $32.9 \%$ of the Canadian nurses are dissatisfied with their job, and they are planning to leave their present jobs. If this is the situation in the developed countries, what is the situation in developing countries. This amount of rating dissatisfaction among nurses confirms that it is a global problem, which means it is rising among nurses, knowing that turnover intention is the most serious ultimate result of job dissatisfaction (Aiken et al., 2002).

Scholars who studied behavioral intentions development suggested that the only significant predictor of people behavior to be measured is the reasoned action model and it is used to report the intention to conduct that behavior, stressing turnover intention as the main factor in the modeling of individual turnover behavior. Overall, turnover 
intention has been strongly recognized as the antecedent of actual turnover, however, job satisfaction as well has been found to have a converse relationship with turnover intention (Egan et al., 2004).

\section{Theoretical Development}

Turnover intention is inevitable in the life of an employee. Based on a US Department of Labor study on the 20-24 age group, the average employee will shift from one job to another 6.6 times during his/her lifetime, but those in the 24-34 age group will shift 4.8 times, while those who are in the 45-54 group perhaps will change their jobs 1.4 times before they got retired, assuming that the employees basically discharged for 2 main causes: inability to perform and unwillingness to perform (Josef C. Augustine, 1986).

Employee retaining strategies have a great influence on the individual attachment both direct effect (higher salaries) and indirect effect (through organizational experience) on turnover intention (Anvari, 2010).

Because of the nature of the direction of influence, the complexity of defining and measuring the antecedents and predictors of turnover intention required further research to expose additional antecedents and predictors of turnover intention (Trevor \& Nyberg, 2008)

However, (Holtom et al., 2005) suggested other reasons could be the cause of turnover intention: Level of pay, Lack of promotional opportunities. A career with promotional opportunities will be more likely to be to keep employees away from turnover intention or even actual turnover. Employees will stay longer if they believe that their job has a career promotion (Valencia, 2002).

Furthermore, supervisors and managers in the nursing workplace are working as a model and mentor. They are responsible to deal with directing and working out all issues in their units along with their job in future planning in the strategic level (Kotter, 1999). Mobley (1979) and others suggested some other variables like pay level, commitment, social integration, promotional opportunities.

Theoretically, there is not enough effort which has been done to investigate the correlation between leadership behavior and turnover intention in nursing. However, they confirmed that high performance managers and supervisor's leadership style will lead their employees perceive a high satisfied work environment and an exceptional work climate and as a result high job satisfaction (Sellgran et al., 2007).

Cook (2001) points out five features which have very significant effects on nursing leaders: supporting, creativity, highlighting, influencing and respecting. He emphasizes that creativity is a significant component of a strong leadership style.

Organizational factors aspects have different effects on turnover intention, particularly among registered nurses; thus, studying these aspects is necessary. In the previous studies, there is a lack of studies that have been conducted to examine the effect of organizational factors and turnover intention among registered nurses. Considering these studies have focused on the importance of different organizational factors such as job related, and individual factors, and still there is a gap ininvestigating the effect of leadership, pay level, and advancement opportunities on turnover intention among registered nurses.

\section{Materials and Methods}

In this article we will provide a logical understanding of turnover intention and organizational factors contributions on registered nurses workplace. For this purpose, a thorough search of journal articles, doctoral dissertations, research studies, reports and web sites were done, we developed a comprehensive model that contain the relationships organizational factors, registered nurses'turnover intention. Finally, our discussion consists of four sections and each section literature to support the relation between the organizational factors: leadership, pay level, advancement opportunities and the turnover intention.

\section{Discussion}

\subsection{The Organizational Factors Competences}

Since turnover intention in the health care system is a very serious global dilemma, human recourse mangers are demanding to search and to find solutions. Scholars and researchers suggested organizational variables such as pay level, promotional opportunities, and supervisors (leadership) have a significant influence on turnover intention among nurses Mobley (1979). In this paper, organizational factors are examined under three components, (leadership, pay level, and advancement opportunities) and is defined as "the perceived properties or characteristics found in the work environment that result from actions taken consciously or unconsciously by an organization and that presumably affect subsequent behavior" (Steers \& Lee, 1983, p. 82). The elements of organizational factors are as follows: 


\subsubsection{Leadership}

Supervisors and managers in the nursing workplace are working as a model and mentor. They are responsible to deal with directing and working out all issues in their units along with their job in future planning in the strategic level (Kotter, 1999). Many scholars in this day believe that success in managing or supervising in modern and sophisticated workplace or any organization involves leadership capabilities. However, the manger's function is more likely to be focusing on the relationship between his/ her staff, ensuring high efficiency with high quality of his/her unit outcomes, and ultimately his/ her role as coach to his/her own staff (Yuki, 2002).

The type of supportive leaders has been considered as one of the leadership behavior styles that has significant effects on job satisfaction and retention and diminish the rate of employee's turnover intention in the nursing workplace (Albaugh, 2003).

\subsubsection{Pay Level}

The rewards system in any organization is the technique to barter the employee's services in their efforts to achieve the organization's objectives, by the organization's rewards and compensation system. However, monetary pay is the most common and the most important element (Bartol \& Locke, 2000; Graham \& Welbourne, 1999). No doubt that pay can be the most significant motivation factor and the best element to encourage the employees to stay and increase the retention level among them (Lum et al., 1998).

On the other hand, money could be issues of inequity among the employees that weaken $t$ positive pay impact and instead have a negative consequence. As a matter of fact, most of the employees all over the globe feel unsatisfied with their employer's compensation system (Tekleab et al., 2005).

\subsubsection{Advancement Opportunities}

Career advancement is given a higher rank in terms of value to an organization, as every employee is eager to know about it whenever he/ she enters his/ her life's career. The career advancement opportunities have to be a clear, enlightened, and known to every new employee. To most scholars career advancement is related to seniority, advantage and merit. Moreover, for others, especially psychological scientist and management as well, advancement opportunities are often being seen as a sign of the significant reason for some employees to dislike their work, and could act as factor which affects the degree of job satisfaction, which could ultimately be an enhancement for turnover intention among new employees and old ones as well (Edem, 2000).

Wei Zhao (2008) argued that the decision to leave or turnover intention among employees will rely on steady considerations of the advancement opportunities within their present job in comparison with other jobs in the labour market.

Job status or job position typically refers to the supremacy and power along with the prestige within the workplace. In this perspective, high job position refers to more individual's self- esteem (Wei Zhao, 2008).

\subsection{The Relationship between Leadership and Turnover Intention}

Sellgren et al. (2007) confirmed that there is a strong relationship between leadership styles and the organizational work environment and they emphasized that this relationship is very important because there is a great correlation between work environment and work climate and job satisfaction level which as a result have a significant relationship with the nursing turnover behavior. Furthermore, Supervisors or managers in the nursing work place have very significant roles in nurse retention and their turnover behavior. Their results show the effect of leadership styles on employee's turnover intention with the mediating role of job satisfaction.

Numerous scholars and researchers have been exploring the nature and notion of the relationship between leadership style and employees' turnover intention. In the same context, Bass (1990) suggested that most of previous studies show that leadership behavior could be a key element and a vital key in reducing and justifying staff turnover intention. Furthermore, it was found that leadership style was in many different ways related in one way or another to employee's turnover intention among staff for numerous firms and organizations, and in the nursing workplace. It was found that there is a stronger relationship between leadership style and turnover intention among the nurses (Bycio, 1995). In their attempt to investigate the nature of the strength of the relationship between leadership style and turnover intention, Wells \& Peachey (2011) carried out a study among 200 National Colleges assistant coaches, and in U.S.A, they found that there is a strong negative relationship between leadership style and turnover intention.

\subsection{The Relationship between Pay Level and Turnover Intention}

Two key issues should be considered regarding the salaries or pay level within the organization. These twoissues of unfairness usually are complaints by the employees which are distributive justice and procedural justice. 
Distributive justice as an essential matter and procedural justice is a secondary issue. In all cases, distributive justice means the level to which staffs perceive pay quantity as fair, while procedural justice is about the fairness in the technique or system used to estimate the employee's amount of his salary or payment. However, most of the studies till recent time is still mixed. The effects of these two types are on pay justice on the employee satisfaction and eventually, turnover intention (Bergmann \& Scarpello, 2001; Gerhart \& Rynes, 2003).

Most of the studies have examined the impact of justice compensation on employees' turnover intention. Obviously, the outcome of those studies suggested that employees who are dissatisfied with their salaries because of unfairness of distributive and procedural justice as a result will have a higher desire and willingness to quit their jobs. In many turnover intention research models, pay satisfaction is assumed to be a key factor impact on the willingness of the employees to leave the organization and subsequently as a turnover behavior among the organization's employees (Tekleab et al., 2005). Furthermore, numerous related studies have suggested that a negative relationship existed between pay level satisfaction and employee turnover intention (Lum et al., 1998).

Folger and Konovsky (1989) suggested a key relationship between pay raise and organizational commitment, which will have a negative impact on employee's turnover intention.

\subsection{The Relationship between Advancement Opportunities and Turnover Intention}

Turnover intention could be very disturbing to any employee's career progress and destroy his/ her career achievement. Unsatisfactory career progress is a dynamic pushing force in turnover intention. Logically, if an employee has a very successful career status and his/ her future advancement in this career show signs of brightness, he / she will not have any intention to leave the organization. On the other hand if he/ she is not satisfied with his/ her advancement opportunities within the organization, this will enhance the turnover intention desirability. Based on that, they presume that unsatisfied advancement opportunities are a significant trigger for turnover intention (Wei Zhao, 2008).

Employee's position and rank promotion means that he/ she is the manager's favorable choice, promotion stand for the employee superiority among the other employees in the organization in terms of the organizational standard skills and qualifications (Lazear, 1999). On the other hand, poor upward mobility could mean that an employee has reached his/her career peak advancement. Such image will push the employees to seek better job alternative with favorable advancement opportunities, and make negative impact on job satisfaction degree within the organization which will lead to turnover intention (Lee et al., 1996).

Poor advancement opportunities within the organization compared with other organizations within the industry may trigger the feeling of comparative deprivation. Career promotions lower than the expectation could harm the reputation of organization's justice which will lead to employee dissatisfaction. Eventually this will increase turnover intention or actual turnover among the employees (Aquino, 1999; Heslin, 2005; Wei Zhao, 2008).

\section{Conclusion}

This paper contributes to both organizational factors literature and turnover intention in many ways. Firstly, it provides a theoretical support for the relationship between organizational factors and registered nurses turnover intention. Secondly, this paper contributes to the nursing workplace literature by shading more light on some of the organizational components and the relationship between these components and how effects nurses turnover intention. Thirdly, this conceptual paper enriches the nursing workplace literature by explaining some of the organizational factorscan affectnurses' effectiveness in nursing workplace all over the world.

\section{References}

Aiken, L. H., Clarke, S. P., Sloane, D. M., Sochalski, J., \& Silber, J. H. (2002). Hospital nurse staffing and patient mortality, nurse burnout, and job dissatisfaction. JAMA: the journal of the American Medical Association, 288(16), 1987-1993. http://dx.doi.org/10.1001/jama.288.16.1987

Albaugh, J. (2003). Keeping nurses in nursing: the profession's challenge for today. Urologic Nursing, 23(3), 193.

Anvari, R., Amin, S. M., Ismail, W. K. W., \& Ahmad, U. N. U. (2010). Strategic training practices, effective organizational commitment, and turnover intention: The mediating role of psychological contract. Afr. J. Bus. Manage, 4(15), 3391-3405.

Aquino, K., Lewis, M. U., \& Bradfield, M. (1999). Justice constructs, negative affectivity, and employee deviance: A proposed model and empirical test. Journal of Organizational Behavior, 20(7), 1073-1091. http://dx.doi.org/10.1002/(SICI)1099-1379(199912)20:7<1073::AID-JOB943>3.0.CO;2-7

Bartol, K. M., \& Locke, E. A. (2000). Incentives and motivation. Compensation in organizations: Current research and practice, 104-147. 
Bass, B. M. (1990). From transactional to transformational leadership: Learning to share the vision. Organizational dynamics, 18(3), 19-31. http://dx.doi.org/10.1016/0090-2616(90)90061-S

Bergmann, T. J., Scarpello, V. G., \& Hills, F. S. (1998). Compensation decision making. Dryden Press.

Bycio, P., Hackett, R. D., \& Allen, J. S. (1995). Further assessments of Bass's (1985) conceptualization of transactional and transformational leadership. Journal of applied psychology, 80(4), 468. http://dx.doi.org/10.1037/0021-9010.80.4.468

Cook, M. J. (2001). The attributes of effective clinical nurse leaders. Nursing standard (Royal College of Nursing (Great Britain): 1987), 15(35), 33.

Eden, D., Geller, D., Gewirtz, A., Gordon-Terner, R., Inbar, I., Liberman, M. et al. (2000). Implanting Pygmalion leadership style through workshop training: Seven field experiments. The Leadership Quarterly, 11(2), 171-210. http://dx.doi.org/10.1016/S1048-9843(00)00042-4

Egan, T. M., Yang, B., \& Bartlett, K. R. (2004). The effects of organizational learning culture and job satisfaction on motivation to transfer learning and turnover intention. Human resource development quarterly, 15(3), 279-301. http://dx.doi.org/10.1002/hrdq.1104

Folger, R., \& Konovsky, M. A. (1989). Effects of procedural and distributive justice on reactions to pay raise decisions. Academy of Management journal, 32(1), 115-130. http://dx.doi.org/10.2307/256422

Frank, F. D., Finnegan, R. P., \& Taylor, C. R. (2004). The race for talent: retaining and engaging workers in the 21 st century. Human Resource Planning, 27(3), 12-25.

Gerhart, B., \& Rynes, S. (2003). Compensation: Theory, evidence, and strategic implications. SAGE Publications, Incorporated.

Heslin, P. A. (2005). Conceptualizing and evaluating career success. Journal of Organizational Behavior, 26(2), 113-136. http://dx.doi.org/10.1002/job.270

Holtom, B. C., Mitchell, T. R., Lee, T. W., \& Inderrieden, E. J. (2005). Shocks as causes of turnover: What they are and how organizations can manage them. Human Resource Management, 44(3), 337-352. http://dx.doi.org/10.1002/hrm.20074

Kotter, J. P. (1999). John P. Kotter on what leaders really do. Harvard Business Press.

Lazear, E. P. (1999). Personnel economics: past lessons and future directions. National Bureau of Economic Research. http://dx.doi.org/10.3386/w6957

Lee, T. W., Mitchell, T. R., Wise, L., \& Fireman, S. (1996). An unfolding model of voluntary employee turnover. Academy of Management journal, 39(1), 5-36. http://dx.doi.org/10.2307/256629

Mobley, W. H. et al. (1979). Review and conceptual analysis of the employee turnover process. Psychological bulletin, 86(3), 493. http://dx.doi.org/10.1037/0033-2909.86.3.493

Morrell, K. M., Loan-Clarke, J., \& Wilkinson, A. J. (2004). Organisational change and employee turnover. Personnel Review, 33(2), 161-173. http://dx.doi.org/10.1108/00483480410518022

Sellgren, S., Ekvall, G., \& Tomson, G. (2007). Nursing staff turnover: does leadership matter? Leadership in Health Services, 20(3), 169-183. http://dx.doi.org/10.1108/17511870710764023

Steers, R. M., \& Lee, T. W. (1982). Facilitating Effective Performance Appraisals: The Role of Employee Commitment and Organizational Climate. No. TR-10-ONR. OREGON UNIV EUGENE GRADUATE SCHOOL OF MANAGEMENT.

Tekleab, A. G., Takeuchi, R., \& Taylor, M. S. (2005). Extending the Chain of Relationships among Organizational Justice, Social Exchange, and Employee Reactions: The Role of Contract Violations. Academy of Management Journal, 48(1), 146-157. http://dx.doi.org/10.5465/AMJ.2005.15993162

Trevor, C. O., \& Nyberg, A. J. (2008). Keeping your headcount when all about you are losing theirs: Downsizing, voluntary turnover rates, and the moderating role of HR practices. Academy of Management Journal, 51(2), 259-276. http://dx.doi.org/10.5465/AMJ.2008.31767250

Valencia, R. R. (2002). Chicano school failure and success: Past, present, and future. Routledge.

Wells, J. E., \& Peachey, J. W. (2011). Turnover intentions: Do leadership behaviors and satisfaction with the leader matter? Team Performance Management, $17(1 / 2), \quad$ 23-40. http://dx.doi.org/10.1108/13527591111114693 
Yukl, G., Gordon, A., \& Taber, T. (2002). A hierarchical taxonomy of leadership behavior: Integrating a half century of behavior research. Journal of Leadership \& Organizational Studies, 9(1), 15-32. http://dx.doi.org/10.1177/107179190200900102

Zhao, W., \& Zhou, X. (2008). Intraorganizational career advancement and voluntary turnover in a multinational bank in Taiwan. Career Development International. http://dx.doi.org/10.1108/13620430810891446

\section{Copyrights}

Copyright for this article is retained by the author(s), with first publication rights granted to the journal.

This is an open-access article distributed under the terms and conditions of the Creative Commons Attribution license (http://creativecommons.org/licenses/by/3.0/). 